\title{
NoTe
}

\section{Isolated ACTH Deficiency with Graves' Disease: A Case Report}

\author{
SHOZO MIYAUCHI, YOSHIMASA YAMASHITA, BUNZO MATSUURA* AND MORIKAZU ONJI* \\ Department of Internal Medicine, Uwajima Municipal Hospital, 1-1 Goten-machi, Uwajima, Ehime 798-8510, Japan \\ *Third Department of Internal Medicine, Ehime University School of Medicine, Shitsukawa, Shigenobu, Onsen-gun, Ehime 791- \\ 0295, Japan
}

\begin{abstract}
A 60-year-old man was hospitalized with complaints of general malaise and weight loss. On admission, ACTH and cortisol levels were low, and thyroid function tests revealed hyperthyroidism. These findings and further examination led to a diagnosis of isolated ACTH deficiency (IAD) with Graves' disease. It is known that IAD is frequently associated with thyroid disease, but its association with Graves' disease is rare. The present case is worth noting, because some reports indicate that aggravation of associated Graves' disease may concomitantly aggravate adrenal insufficiency in patients with IAD.
\end{abstract}

Key words: Isolated ACTH deficiency, Graves' disease

(Endocrine Journal 51: 115-119, 2004)

ISOLATED ACTH deficiency (IAD) is frequently associated with thyroid disease [1] including Hashimoto's disease [2, 3] and primary hypothyroidism [4, 5]. However, its association with Graves' disease is rare. In this report, we present a case of IAD with Graves' disease.

\section{Case report}

A 60-year-old man was hospitalized with complaints of general malaise and weight loss. He had a past history of Addison's disease and hyperthyroidism diagnosed at age 47. He had taken thiamazole (MMI) $5 \mathrm{mg} /$ day and cortisone acetate $\left(\right.$ Cortone $\left.^{\mathrm{R}}\right) 25 \mathrm{mg} /$ day thereafter. However, he took these agents irregularly and had not taken these agents for 2 weeks prior to admission.

The patient was thin, weighing $39.8 \mathrm{~kg}$, and was $150.7 \mathrm{~cm}$ in height. Body temperature was $36.5^{\circ} \mathrm{C}$.

Received: March 3, 2003

Accepted: October 24, 2003

Correspondence to: Shozo MIYAUCHI, M.D., Department of Internal Medicine, Uwajima Municipal Hospital, 1-1 Gotenmachi, Uwajima, Ehime 798-8510, Japan
Blood pressure was $118 / 82 \mathrm{mmHg}$. Pulse rate was 90 per min with normal sinus rhythm. Consciousness was clear. There was neither exophthalmos nor struma. Mild finger tremor was observed. Skin was normally moist without pigmentation. Neither the pubic nor axillary hair was scanty. Examination of the nervous system revealed no abnormalities. Hormonal data on admission are shown in Table 1. Serum TSH concentration was decreased and $\mathrm{FT}_{3}$ concentration was in-

Table 1. Hormonal data on admission (2001/9/25)

1. Basal levels

\begin{tabular}{lll}
\hline ACTH & $6.8 \mathrm{pg} / \mathrm{mL}$ & $(9.0-52.0 \mathrm{pg} / \mathrm{mL})$ \\
$\mathrm{TSH}$ & $0.01 \mu \mathrm{IU} / \mathrm{mL}$ & $(0.54-4.54 \mu \mathrm{IU} / \mathrm{mL})$ \\
$\mathrm{LH}$ & $3.8 \mathrm{mIU} / \mathrm{mL}$ & $(1.1-8.8 \mathrm{mIU} / \mathrm{mL})$ \\
$\mathrm{FSH}$ & $4.5 \mathrm{mIU} / \mathrm{mL}$ & $(1.8-13.6 \mathrm{mIU} / \mathrm{mL})$ \\
$\mathrm{GH}$ & $5.7 \mathrm{ng} / \mathrm{mL}$ & $(<5.6 \mathrm{ng} / \mathrm{mL})$ \\
$\mathrm{PRL}$ & $3.6 \mathrm{ng} / \mathrm{mL}$ & $(1.5-9.7 \mathrm{ng} / \mathrm{mL})$ \\
Cortisol & $0.9 \mu \mathrm{g} / \mathrm{dL}$ & $(5.0-15.0 \mu \mathrm{g} / \mathrm{dL})$ \\
Aldosterone & $1.1 \mathrm{ng} / \mathrm{dL}$ & $(3.6-24.0 \mathrm{ng} / \mathrm{dL})$ \\
PRA & $0.4 \mathrm{ng} / \mathrm{mL} / \mathrm{h}$ & $(0.1-2.0 \mathrm{ng} / \mathrm{mL} / \mathrm{h})$ \\
$\mathrm{FT}_{3}$ & $5.10 \mathrm{pg} / \mathrm{mL}$ & $(2.70-4.30 \mathrm{pg} / \mathrm{mL})$ \\
$\mathrm{FT}_{4}$ & $1.21 \mathrm{ng} / \mathrm{dL}$ & $(1.10-1.80 \mathrm{ng} / \mathrm{dL})$ \\
DHEA-S & $344 \mathrm{ng} / \mathrm{mL}$ & $(150-2400 \mathrm{ng} / \mathrm{mL})$ \\
& & ()$:$ normal range
\end{tabular}

PRA, plasma renin activity; $\mathrm{FT}_{4}$, free thyroxine; $\mathrm{FT}_{3}$, free triiodothyronine; DHEA-S, dehydroepiandrosterone sulfate; 
Table 2. Hormonal data in detailed examination (2001/10/1811/9)

\begin{tabular}{lll} 
1. Basal levels & & \\
\hline ACTH & $6.8 \mathrm{pg} / \mathrm{mL}$ & $(9.0-52.0 \mathrm{pg} / \mathrm{mL})$ \\
$\mathrm{TSH}$ & $3.76 \mu \mathrm{IU} / \mathrm{mL}$ & $(0.54-4.54 \mu \mathrm{IU} / \mathrm{mL})$ \\
Cortisol & $1.1 \mu \mathrm{g} / \mathrm{dL}$ & $(5.0-15.0 \mu \mathrm{g} / \mathrm{dL})$ \\
$\mathrm{FT}_{3}$ & $2.97 \mathrm{pg} / \mathrm{mL}$ & $(2.70-4.30 \mathrm{pg} / \mathrm{mL})$ \\
$\mathrm{FT}_{4}$ & $0.67 \mathrm{ng} / \mathrm{dL}$ & $(1.10-1.80 \mathrm{ng} / \mathrm{dL})$ \\
Urine $17-\mathrm{OHCS}$ & $0.15 \mathrm{mg} /$ day & $(3.40-12.00 \mathrm{mg} /$ day $)$ \\
Urine $17-\mathrm{KS}$ & $0.22 \mathrm{mg} /$ day & $(4.60-18.00 \mathrm{mg} /$ day $)$ \\
Urine free cortisol & $<5.0 \mu \mathrm{g} /$ day & $(11.2-80.3 \mu \mathrm{g} /$ day $)$ \\
UM & $0.06 \mathrm{mg} /$ day & $(0.04-0.18 \mathrm{mg} /$ day $)$ \\
UNM & $0.24 \mathrm{mg} /$ day & $(0.10-0.28 \mathrm{mg} /$ day $)$ \\
& & ()$:$ normal range \\
\hline
\end{tabular}

17-OHCS, 17-hydroxycorticosteroid; 17-KS, 17-ketosteroid; UM, urine metanephrine; UNM, urine normetanephrine.

2. Rapid ACTH test

\begin{tabular}{cccc}
\hline Time $(\mathrm{min})$ & 0 & 30 & 60 \\
\hline Cortisol $(\mu \mathrm{g} / \mathrm{dL})$ & 1.1 & 2.2 & 2.4 \\
\hline
\end{tabular}

3. Prolonged ACTH test

\begin{tabular}{ccccccc}
\hline Day & 1 & 2 & 3 & 4 & 5 & 6 \\
\hline 17-OHCS (mg/day) & 3.20 & 3.20 & 5.40 & 6.50 & 8.90 & 9.00 \\
\hline
\end{tabular}

4. CRH, TRH, LHRH, GRH test

\begin{tabular}{lcccc}
\hline Time $(\mathrm{min})$ & 0 & 30 & 60 & 120 \\
\hline ACTH $(\mathrm{pg} / \mathrm{mL})$ & $<5.0$ & 6.3 & 6.8 & $<5.0$ \\
TSH $(\mu \mathrm{IU} / \mathrm{mL})$ & 3.76 & 35.04 & 28.31 & 16.44 \\
LH $(\mathrm{mIU} / \mathrm{mL})$ & 3.3 & 25.3 & 27.0 & 19.1 \\
FSH $(\mathrm{mIU} / \mathrm{mL})$ & 4.5 & 9.4 & 11.2 & 10.2 \\
GH $(\mathrm{ng} / \mathrm{mL})$ & 1.1 & 25.8 & 48.4 & 19.7 \\
PRL $(\mathrm{ng} / \mathrm{mL})$ & 3.2 & 34.1 & 21.5 & 10.3 \\
\hline
\end{tabular}

5. Prolonged CRH test

\begin{tabular}{ccccc}
\hline Time $(\mathrm{min})$ & 0 & 30 & 60 & 120 \\
\hline ACTH $(\mathrm{pg} / \mathrm{mL})$ & 6.1 & $<5.0$ & $<5.0$ & 6.7 \\
Cortisol $(\mu \mathrm{g} / \mathrm{dL})$ & 1.3 & 1.0 & 0.8 & 0.8 \\
\hline
\end{tabular}

creased. Basal concentrations of plasma ACTH and serum cortisol were decreased. Once thyroid and adrenal function was brought under control with MMI $5 \mathrm{mg} /$ day and Cortone $\mathrm{R}^{\mathrm{R}} 25 \mathrm{mg}$ /day for 21 days, the following blood examinations were performed.

After Cortone ${ }^{R}$ was stopped for three days, the patient underwent further detailed endocrine investigation, the results of which are shown in Table 2. Thyroid function was brought to normal range, but
Table 3. Immunological data on admission (2001/9/25)

\begin{tabular}{lll}
\hline TSAb & $835 \%(<180 \%)$ & \\
TgAb & $41.3 \mathrm{U} / \mathrm{mL}$ & $(<0.3 \mathrm{U} / \mathrm{mL})$ \\
TPOAb & $53.6 \mathrm{U} / \mathrm{mL}$ & $(<0.3 \mathrm{U} / \mathrm{mL})$ \\
$\mathrm{ANA}$ & $<1: 40$ & $(<1: 80)$ \\
$\mathrm{RF}$ & $<4 \mathrm{IU} / \mathrm{mL}$ & $(<20 \mathrm{IU} / \mathrm{mL})$ \\
$\mathrm{PitAb}$ & $22 \mathrm{kDa}(-)$ & \\
& $49 \mathrm{kDa}(-)$ & \\
& & $($ ): normal range \\
\hline
\end{tabular}

TSAb, thyroid stimulating antibody; TPO, thyroid peroxidase; $\mathrm{Tg}$, thyroglobulin; ANA, anti nucleic antibody; RF, rheumatoid factor; PitAb, anti-pituitary antibody.

the basal levels of plasma ACTH and serum cortisol were low. Serum cortisol concentration was not increased after intravenous injection of ACTH $250 \mu \mathrm{g}$, but the urinary output of 17-hydroxycorticosteroid was increased to normal level after intramuscular injection of long-acting ACTH $1 \mathrm{mg}$ for three days. Plasma $\mathrm{ACTH}$ did not respond to either intravenous injection of $\mathrm{CRH}$, or to prolonged CRH $(100 \mu \mathrm{g} /$ day for five days) stimulation test. Serum concentrations of GH, LH, FSH and PRL increased to normal response levels following intravenous injection of TRH $500 \mu \mathrm{g}$, GRH $100 \mu \mathrm{g}$ and LH-RH $100 \mu \mathrm{g}$. These findings indicated primary hyperthyroidism and secondary adrenocortical insufficiency.

Immunological studies are shown in Table 3. The patient was seropositive for serum thyroid stimulating antibody, anti-thyroglobulin antibody, and anti-thyroid peroxidase antibody. Anti-pituitary antibodies were negative.

The image of ${ }^{123} \mathrm{I}$ thyroid scintigram on admission showed diffuse uptake into the thyroid and the 24-hour uptake ratio increased (43.5\%). Ultrasound tomogram of the thyroid revealed moderate and diffuse enlargement without nodules. Abdominal ultrasonogram yielded no abnormal findings. Magnetic resonance imaging of the pituitary gland revealed empty sella.

Based on these results, the patient was diagnosed with IAD associated with Graves' disease, and the therapy with $25 \mathrm{mg}$ /day of Cortone $\mathrm{R}^{\mathrm{R}}$ was started again. After initiation of medication, his symptoms disappeared and he was discharged. 


\section{Discussion}

On admission, the patient's complaints were general malaise and weight loss. Furthermore, serum $\mathrm{FT}_{3}$ level and TSH level showed hyperthyroid state, TSAb was positive and the uptake ratio of ${ }^{123}$ I thyroid scintigram increased. Therefore, we initially considered his symptoms to be due to the hyperthyroidism of $\mathrm{T}_{3}$ dominant type Graves' disease. However, further examination demonstrated low levels of plasma ACTH and serum cortisol, and normal values of other pituitary hormones. These findings indicated that the patient was complicated of secondary adrenocortical insufficiency. After thyroid and adrenocortical functions were normalized with MMI and Cortone ${ }^{\mathrm{R}}$, pituitary stimulation test was performed. Plasma ACTH level did not respond to CRH stimulation, but the levels of other pituitary hormones exhibited normal response patterns. ACTH exhibited no response to prolonged CRH test. Therefore, the final diagnosis of IAD was established. Addison's disease was ruled out by the result that urine 17-OHCS level exhibited a gradual increase on prolonged ACTH test.

According to our review of the literature, a total of 304 cases of IAD were reported from 1969 to 1994 in Japan [1]. Of the 304 cases, 88 (28.9\%) were associated with thyroid disorders, including Hashimoto's thyroiditis (39 cases, 12.8\%), primary hypothyroidism, not otherwise specified (34 cases, 11.1\%), and hyper- thyroidism (4 cases, 1.3\%). Since 1995, four authentic cases of IAD with Graves' disease have been added to the Japanese literature [6-9].

Although the etiology of IAD remains uncertain in most cases, an autoimmune mechanism is thought to be responsible in some cases, as suggested by the histological evidence of lymphocytic hypophysitis, by the frequent detection of anti-pituitary antibodies, and by an association with other autoimmune disorders [10]. Ishihara et al. reported that the height of the pituitary gland with lymphocytic hypophysitis gradually decreased and the pituitary finally showed empty sella [11] and Hashimoto et al. reported that IAD is often seen in the patient with lymphocytic hypophysitis [12]. In the present case, the MRI image of the pituitary showed empty sella and Graves' disease was complicated. Therefore, we considered IAD to be caused by lymphocytic hypophysitis in the present case. However, there were neither anti-pituitary antibodies nor other autoimmune markers without thyroid antibodies. Anti-pituitary antibodies to a $22-\mathrm{kDa}$ human pituitary cytosolic protein were identified in sera from patient with lymphocytic hypophysitis (73.3\%), and antipituitary antibodies to $49-\mathrm{kDa}$ human pituitary cytosolic protein were seen in the patients with lymphocytic hypophysitis $(40.0 \%)$, but a diagnosis of lymphocytic hypophysitis by anti-pituitary antibodies is not established $[10,12]$. For that reason, although anti-pituitary antibodies were not identified in the present case, we

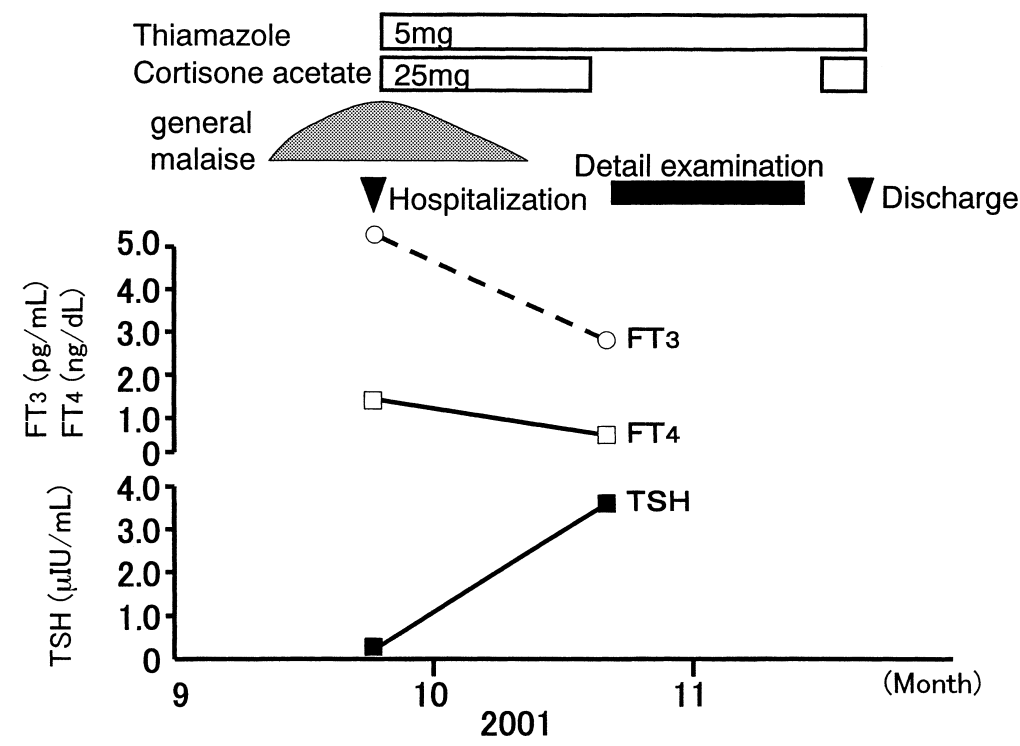

Fig. 1. Clinical course of the present case. After the thyroid function was controlled with thiamazole ( $5 \mathrm{mg} / \mathrm{day})$, general malaise disappeared and cortisone acetate could be suspended for tolerance tests. 
could not rule out the possibility that IAD may have been caused by lymphocytic hypophysitis. No other complications were recognized in the present case, although IAD has been reported after head injury [13], in association with diabetes mellitus [14] and with benign intracranial hypertension [15]. Therefore, the etiology of IAD in the present case is not clear.

When endocrine diseases overlap in the same patient, it is necessary to consider autoimmune polyglandular syndrome [16, 17]. Although an autoimmune thyroid disease was diagnosed in the present case, there was neither type 1 diabetes mellitus nor autoimmune pituitary disease. Therefore, we ruled out autoimmune polyglandular syndrome in the present case.

The clinical course of the present case is shown in Fig. 1. This patient complained of general malaise at hospitalization. However, once MMI and Cortone ${ }^{R}$ were medicated, the symptom was gradually reduced. As soon as thyroid function was normalized, the symptom disappeared. Finally, although oral administration of Cortone $\mathrm{R}^{\mathrm{R}}$ could be suspended for tolerance tests, the subjective symptom of adrenocortical insufficiency did not develop. Therefore, it is conjectured that hyperthyroidism exacerbated adrenocortical insufficiency in the present case.

Concerning the relationship between IAD and hyperthyroidism reported in the literature, we assumed that the aggravation of Graves' disease in the present case aggravated the patient's adrenal insufficiency. This assumption is supported by several reports that hyperthyroidism due to Graves' disease can aggravate adrenal insufficiency in patients with IAD $[6,8]$.

In the present case, aggravation of Graves' disease probably occurred because the patient took medication for it irregularly. Isotope therapy or surgery may be needed for this patient in the near future.

\section{Acknowledgement}

We thank Prof. Kozo Hashimoto, Second Department of Internal Medicine, Kochi Medical School, for performing the anti-pituitary antibody measurement.

\section{References}

1. Hashimoto K (1995) Isolated ACTH deficiency. Endocrinol Diabetol 1: 103-111 (In Japanese).

2. Kamijo K, Kato T, Saito A, Kawasaki K, Suzuki M, Yachi A (1982) A case with isolated ACTH deficiency accompanying chronic thyroiditis. Endocrinol Jpn 29: 183-189.

3. Okuno S, Inaba M, Nishizawa Y, Morii H (1993) Isolated ACTH deficiency associated with Hashimoto disease. Nippon Rinsho 51: 2721-2725 (In Japanese).

4. Yamamoto T, Ogihara T, Miyai K, Kumahara Y, Hirata Y (1976) Co-existent primary hypothyroidism and isolated ACTH deficiency. Acta Endocrinol (Copenh) 82: 467-474.

5. Roosens B, Maes E, Van Steirteghem A, Vanhaelst L (1982) Primary hypothyroidism associated with secondary adrenocortical insufficiency. $J$ Endocrinol Invest 5: 251-254.

6. Kato R, Mokuno T, Hayakawa N, Shimazaki K, Ito Y, Fukushima M, Ito M, Nagasaka A, Nakagawa H (1995) A case of isolated ACTH deficiency with Graves' disease and with acute adrenal insufficiency. Nippon Naibunpitsu Gakkai Zasshi (Folia Endocrinol Jpn) 71: 1000 (Abstract) (In Japanese).

7. Takano J, Ishidou H, Kitaoka M, Fujita T (1995) An isolated ACTH deficiency with diabetes mellitus and Graves' disease, muscular weakness, pain of whole body, and disturbance of consciousness. Nippon Naibunpitsu Gakkai Zasshi (Folia Endocrinol Jpn) 74: 67 (Abstract) (In Japanese).

8. Muto N, Ito Y, Komaki T, Yamakita Y, Ikeda Y (1996) A case of the isolated ACTH deficiency with Graves' disease and empty sella. Hormone to Rinsho 44: 45-49 (In Japanese).

9. Matsuo T, Takamatsu J, Makino S, Fukao A, Kaji K, Nagata K, Gouda K, Kure M, Fujita A, Sasaki M, Sakane S, Osawa N (2000) A case of Graves' disease with ACTH deficiency and with aggravation of SLE. Hormone to Rinsho 48: 92-96 (In Japanese).

10. Takao T, Nanamiya W, Matsumoto R, Asaba K, Okabayashi T, Hashimoto K (2001) Antipituitary antibodies in patients with lymphocytic hypophysitis. Horm Res 55: 288-292.

11. Ishihara $T$, Hino $M$, Kurahachi $H$, Kobayashi $H$, Kajikawa M, Moridera K, Ikekubo K, Hattori N (1996) Long-term clinical course of two cases of lymphocytic adenohypophysitis. Endocr J 43: 433-440.

12. Hashimoto K, Takao T, Makino S (1997) Lymphocytic adenohypophysitis and lymphocytic infundibuloneurohypophysitis. Endocr J 44: 1-10.

13. Gordon D, Beastall GH, Thomson C, Thomson JA (1987) ACTH deficiency: hypothalamic or pituitary in origin? Scott Med J 32: 49-50. 
14. Giustina A, Candrina R, Cimino A, Romanelli G (1988) Development of isolated ACTH deficiency in a man with type I diabetes mellitus. J Endocrinol Invest 11: 375-377.

15. Aanderud S, Jorde R (1988) ACTH deficiency, hyperprolactinemia and benign intracranial hypertension. A case report. Acta Endocrinol (Copenh) 118: 346-350.
16. Neufeld M, Maclaren N K, Blizzard R M (1981) Two types of autoimmune Addison's disease associated with different polyglandular autoimmune (PGA) syndromes. Medicine (Baltimore) 60: 355-362.

17. Betterle C, Greggio N A, Volpato M (1998) Clinical review 93: Autoimmune polyglandular syndrome type 1. J Clin Endocrinol Metab 83: 1049-1055. 